\title{
Nutrients in agroecosystems: Rethinking the management paradigm
}

\author{
L. E. Drinkwater ${ }^{*}$ and S. S. Snapp ${ }^{2}$
}

Short title: Nutrients in agroecosystems

Key words: Agroecosystems, nutrient cycling, coupled biogeochemical processes, plant species functions, microbial community structure and function

*Corresponding author

${ }^{1}$ Associate Professor

Department of Horticulture

Cornell University

Ithaca, New York 14853

607-255-9408

led24@,cornell.edu

${ }^{2}$ Associate Professor, Integrated Crop Management

Department of Horticulture

440A Plant and Soil Sciences Building

Michigan State University

East Lansing, MI 48824-1325

517-355-5187

snapp@msu.edu 


\begin{abstract}
Agricultural intensification has greatly increased the productive capacity of agroecosystems, but has had unintended environmental consequences including degradation of soil and water resources, and alteration of biogeochemical cycles. Current nutrient management strategies aim to deliver soluble inorganic nutrients directly to crops and have uncoupled carbon, nitrogen and phosphorus cycles in space and time. As a result, agricultural ecosystems are maintained in a state of nutrient saturation and are inherently leaky because chronic surplus additions of nitrogen and phosphorus are required to meet yield goals. Significant reductions of nutrient surpluses can only be achieved by managing a variety of intrinsic ecosystem processes at multiple scales to re-couple elemental cycles. Rather than focusing solely on soluble, inorganic plant-available pools, an ecosystem-based approach would seek to optimize organic and mineral reservoirs with longer mean residence times that can be accessed through microbially- and plant-mediated processes. Strategic use of varied nutrient sources, including inorganic fertilizers, combined with increases in plant diversity aimed at expanding the functional roles of plants in agroecosystems will help restore desired agroecosystem functions. To develop crops that can thrive in this environment, selection of cultivars and their associated microorganisms that are able to access a range of nutrient pools will be critical. Integrated management of biogeochemical processes that regulate the cycling of nutrients and carbon combined with increased reservoirs more readily retained in the soil will greatly reduce the need for surplus nutrient additions in agriculture.
\end{abstract}




\section{Introduction}

The unintended consequences of modern agriculture extend well beyond agricultural landscapes themselves (Hambridge 1938; Altieri 1989; Pimentel and others 1991; Matson and others 1997). Biogeochemical cycles have been profoundly altered at multiple scales (Vitousek and others 1997; Carpenter and others 1998) and the rate of soil loss still exceeds soil formation (Pimentel and others 1991). Nitrogen $(\mathrm{N})$ and phosphorus $(\mathrm{P})$ are the two most important nutrients limiting biological production (Chapin and others 1986; Tyrrell 1999) and are the most extensively applied nutrients in managed terrestrial systems, mainly as soluble inorganic fertilizers $\left(\mathrm{F}_{\mathrm{i}}\right)$. Agriculture accounts for $60 \%$ of the biologically active $\mathrm{N}$ from anthropogenic sources (Vitousek and others 1997). Available P in the biosphere has also increased in the last 50 years, largely as a result of $\mathrm{P}$ applications to agricultural lands. Phosphorus flux to coastal oceans has nearly tripled, from $8 \times 10^{6} \mathrm{Mg} \mathrm{yr}^{-1}$ to the current rate of $22 \times 10^{6} \mathrm{Mg} \mathrm{yr}^{-1}$ (Howarth and others 1995). Nutrient enrichment has complex, often detrimental effects in natural ecosystems (Carpenter and Cottingham 1997; Vitousek and others 1997; Galloway 2000). Global N and P fluxes are projected to increase substantially as developing countries increase $\mathrm{F}_{\mathrm{i}}$ production capacity (Tilman 1999; Galloway 2000). A new approach to nutrient supply in intensively managed ecosystems is required to reverse this process of global eutrophication,

In this paper we briefly consider the origin and consequences of the current soil fertility management paradigm. We then present an ecosystem-based conceptual framework that can serve as a basis for nutrient management in agriculture and assess the potential contributions from a wide range of ecosystem processes. Our aim is to critically evaluate the potential for intrinsic ecosystem processes to improve nutrient use efficiency and nutrient balance at the ecosystem scale while maintaining productivity.

\section{Nutrient management in agriculture}

Since the late 1800's, research efforts to improve soil fertility have been based on the premise that agricultural production must continue to increase in order to keep pace with population growth (Crookes 1899; Bear 1926). Initially, $F_{i}$ were viewed as supplemental nutrient sources. During the first half of the twentieth century agriculturalists emphasized the importance of long-term experimentation, temporal plant diversity, maintenance of soil organic matter (SOM) and the need to understand and manage soil biological processes (Waksman 1936; Hopkins 1945; Andrews 1947).

A divergent view, that manufactured $\mathrm{F}_{\mathrm{i}}$ could support high yields without additions of organic amendments and diverse rotations, gained support through the 1940's and 50's to become the dominant paradigm (Hopkins 1945; Tisdale and others 1993). This transition represented a fundamental paradigm shift. The focus of soil fertility management became the relatively small, ephemeral, soluble inorganic $\mathrm{N}$ and $\mathrm{P}$ pools rather than nutrient reservoirs with longer mean residence times (MRT's). As purchased $\mathrm{F}_{\mathrm{i}}$ became more widespread, agronomists sought to minimize fertilizer costs while maximizing yields and profitability through the development of soil tests for plant available nutrients combined with fertilizer trials conducted for a single growing season (Schreiner and Anderson 1938). Dependable soil tests for available P were developed in the late 1940s and have been in common use since the 1960s (Bray and Kurtz 1945; Olsen and others 1954). Predicting plant-available soil $\mathrm{N}$ has proven to be more challenging, and efforts to develop a soil test for $\mathrm{N}$ continue. Currently, the pre-sidedress nitrate test is the most widely recommended soil $\mathrm{N}$ test used to assess plant available $\mathrm{N}$ just before the exponential growth phase of the crop (Magdoff and others 1984).

The impacts of nutrient losses from agricultural lands on aquatic ecosystems became 
apparent in the 1970's prompting a debate about how to best achieve yields without harming the environment (Carpenter and others 1998). As a result, the aim of soil fertility management has broadened to encompass both economic and environmental goals and fertilizer recommendations have undergone substantial refinement and become quite complex (Fig.1). Meanwhile, the "ecological" agriculture paradigm also emerged in the 1980's advocating the application of ecological principles to develop food production systems based on internal, biologically-driven processes in an effort to reduce external inputs while achieving adequate yields (Lowrance and others 1984). The application of ecology in agricultural pest and weed control has become embedded in US agricultural policy, resulting in management options that blend biologicallyand chemically-based strategies (Liebman and Gallandt 1997; Ehler and Bottrell 2000). In contrast, an integrated nutrient management strategy based on ecological concepts has yet to be broadly applied (Tonitto and others 2004).

Instead, the current paradigm guiding nutrient management amounts to a technologically advanced version of the approach developed before the ecosystem concept became a guiding paradigm in ecology. The problem of improved $F_{i}$ use efficiency has been viewed mainly as a consequence of temporal asynchrony and spatial separation between applied nutrients and the crop (Stevenson and Baldwin 1969; Welch and others 1971). As a result, nutrient management research continues to emphasize improved delivery of Fi to the root zone during the period of crop uptake through modifications such as banding, fertigation, and split fertilizer applications (Bolland and Gilkes 1998; Cassman and others 2002). Fertilizer use efficiency is evaluated using metrics that reflect crop uptake of fertilizer added in the current growing season (Cassman and others 2002). To increase crop access to $\mathrm{N}$ fertilizer, a variety of additives have been developed that inhibit nitrification and denitrification (Wolt 2004). This approach has been extremely successful in terms of maximizing yields; however, attempts to reduce nutrient losses have met with limited success (Cassman and others 2002). Despite more than 30 years of concentrated effort, mass balances indicate annual $\mathrm{N}$ and $\mathrm{P}$ inputs consistently exceed harvested exports by 40 to $\geq 100 \%$ resulting in substantial losses of these nutrients to the environment (Bolland and Gilkes 1998; Van der Molen and others 1998; David and Gentry 2000; Galloway and Cowling 2002).

\section{Internal biogeochemical processes in agroecosystems}

The reliance on $\mathrm{F}_{\mathrm{i}}$ combined with use of chemical weed controls has led to a series of management changes that have restructured agroecosystems and uncoupled $\mathrm{N}, \mathrm{P}$ and $\mathrm{C}$ cycles. Simplified rotations became possible when these technologies made it unnecessary to grow cover crops and forages in sequences that alternated with cash crops (Auclair 1976). These crops have little or no cash value per se but help to maintain internal cycling capacity through a variety of mechanisms. Specifically, the preferential removal of winter annuals from large expanses of agricultural lands has increased the prevalence of bare fallows. This reduction in the time frame of living plant cover and C-fixation combined with tillage increases soil erosion and depletion of SOM stocks (Campbell and Zentner 1993; Aref and Wander 1997)and increases the susceptibility of these ecosystems to nutrient saturation and nutrient losses (McCracken and others 1994; Fenn and others 1998; Tonitto and others 2004).

In these simplified rotations where bare fallow is maintained for 4-8 months, microbial assimilation is the only other major route for biologically-mediated retention of added $\mathrm{F}_{\mathrm{i}}$. The arrangement of roots, soil aggregates and pores creates tremendous micro-scale spatial heterogeneity. As a result, environmental conditions favoring either aerobic or anaerobic processes and $\mathrm{N}$-limiting or $\mathrm{C}$-limiting conditions frequently co-occur within the soil matrix (van 
Elsas and van Overbeek 1996). While C-limitation rarely occurs in the rhizosphere (Cheng and others 1996), decomposers in bulk soil are usually C-limited (Koch and others 2001) and less numerous (Rouatt and others 1960). Under the prevailing conditions in agricultural soils, microbial assimilation of $\mathrm{N}$ and $\mathrm{P}$ occurs primarily in the rhizosphere, exactly the same location as plant uptake, while processes contributing to nutrient losses predominate in bulk soil (Smith and Tiedje 1979). Under conditions of surplus $\mathrm{N}$ additions, increased denitrification can also occur in the rhizosphere (Smith and Tiedje 1979).

The reduction of plant-driven sinks in space and time combined with the emphasis on supplying soluble, inorganic nutrients creates a "fertilizer treadmill" that promotes the requirement for chronic surplus additions of $\mathrm{F}_{\mathrm{i}}$. In essence, it is the management framework that resulted from the transition to $F_{i}$ that has created agricultural systems which inadvertantly maximize nutrient saturation in space and time. The concept of ecosystem-scale $\mathrm{N}$ saturation was originally applied to forests receiving anthropogenic $\mathrm{N}$ deposition when the $\mathrm{N}$ additions exceed the capacity of the ecosystem to cycle or store N internally (Agren and Bosatta 1988; Aber and others 1989; Fenn and others 1998). For the purposes of our discussion of agroecosystems, we expand the concept to apply to both $\mathrm{N}$ and $\mathrm{P}$ when availability exceeds the capacity of the ecosystem to cycle or store the nutrients in internal reservoirs that can be accessed by plants or microorganisms.

It is not surprising that the degree of nutrient saturation is greatest in intensive annual crop production systems. In these systems, $\mathrm{NO}_{3}$ leaching is strongly correlated to $\mathrm{N}$ additions (Fig. 2a) indicating that other potential sinks have reached steady-state conditions. Mesocosm studies following the fate of ${ }^{15} \mathrm{~N}$ from organic versus inorganic sources support the idea that microbial assimilation of $\mathrm{F}_{\mathrm{i}}$ in bulk soil is C-limited (Azam and others 1985; Hodge and others 1999). The fate of soluble $P$ is also influenced by $C$ abundance (Kouno and others 2002) because geochemical processes leading to the adsorption and precipitation of $\mathrm{P}$ into occluded pools are reduced when $\mathrm{C}$ is available to drive microbial assimilation of $\mathrm{P}$.

Agronomic ${ }^{15} \mathrm{~N}$ studies indicate that strategies targeting improved crop uptake of $\mathrm{F}_{\mathrm{i}}$ do increase the proportion of $\mathrm{F}_{\mathrm{i}}$ assimilated by the cash crop while permitting farmers to reduce application rates (Mackown and Sutton 1997; Tran and others 1997). However, examination of the fate of ${ }^{15} \mathrm{~N}$ fertilizer in these improved management regimes raises questions about whether this strategy will lead to production systems that approach a balanced steady state. For example, in a recent study, split applications of ${ }^{15} \mathrm{~N}$ fertilizer to wheat achieved comparable yields with less applied $\mathrm{N}$ and reduced $\mathrm{N}$ fertilizer losses (Matson and others 1998). However, since the proportion of fertilizer exported in the wheat increased while proportional $\mathrm{N}$ losses remained the same, the amount of fertilizer remaining in the soil and returned as wheat stubble/roots decreased with reduced $\mathrm{N}$ additions (Fig. 2b). Reductions in the quantity of fertilizer $\mathrm{N}$ entering the internal $\mathrm{N}$ cycle would lead to declines in SON reservoirs and could ultimately reduce yields since the wheat crop obtained about the same amount of $\mathrm{N}$ from the soil in both treatments.

\section{Toward an ecosystem-based approach to improving nutrient use efficiency}

Restoration of ecosystem function and the recoupling of $\mathrm{C}, \mathrm{N}$ and $\mathrm{P}$ can best be accomplished by managing ecosystem processes at a variety of temporal and spatial scales to reduce the need for chronic additions of surplus nutrients. Landscape level strategies that integrate wetlands and other types of riparian buffers into agricultural landscapes are very effective in protecting sensitive natural ecosystems and are a key strategy in ecosystem-scale nutrient management (Lowrance 1992; Mitsch and others 2001). Incorporation of strategically located plant communities that can act as nutrient sinks in managed landscapes can effectively 
capture particulate and soluble nutrients before they reach adjacent waterways or aquatic ecosystems (Mitsch and others 2001).

To complement these strategies, nutrient use efficiency (NUE) within agroecosystems themselves must also be improved. Our conceptual framework for an ecosystem-based approach is outlined in Figure 3. A key feature of this conceptual model is the over-arching goal of developing cropping systems that approach steady states where yields and soil reservoirs are maintained with nutrient inputs that are approximately equal to harvested exports (Fig.3). This will require management of a wider array of ecosystem processes that govern internal cycling capacity such as decomposition, microbial assimilation, biologically-mediated weathering, microbially-mediated $\mathrm{N}$ and $\mathrm{P}$ transformations and soil aggregate formation. Re-coupling $\mathrm{C}, \mathrm{N}$ and $\mathrm{P}$ cycles will reduce the need for chronic additions of surplus nutrients by increasing the sink strength of retention pathways. As a first step, the full range of organic and inorganic nutrient reservoirs must be considered, with the goal of enhancing those with longer MRT's that can be accessed by microorganisms and plants (Fig. 3). Diversification of N and P inputs is an important means of building these pools, through greater use of recycled organic residues, biological N-fixation (BNF) and mineral forms of $\mathrm{P}$ such as apatite. Soluble, inorganic fertilizers should be managed to enhance assimilation of $\mathrm{N}$ and $\mathrm{P}$ in biologically regulated sinks through both plant- and microbially-driven processes.

This framework expands the focus of nutrient management to include a variety of sinks in addition to crop uptake and to explicitly target internal as well as external sources. Enhancing biologically-mediated $\mathrm{N}$ and $\mathrm{P}$ reservoirs will have long-term and cascading impacts on the internal cycling capacity agroecosystems. For example, organic $\mathrm{P}$ reservoirs are challenging to measure and not generally considered to be significant in supplying $\mathrm{P}$ to crops. As a result, organic $\mathrm{P}$ is not measured during routine estimates of soil $\mathrm{P}$ availability although total organic $\mathrm{P}$ is sometimes calculated as the difference between total soil $\mathrm{P}$ and extractable P. However, if we manipulate the relative abundance of $\mathrm{C}$ and $\mathrm{P}$ in the soil, the small organic pools with a rapid turnover rate will compete with geochemical pathways of $\mathrm{P}$ adsorption and absorption that lead to $\mathrm{P}$ occlusion. As result more $\mathrm{P}$ would remain in organic reservoirs which can be accessed by plants either directly or through collaboration with microbes.

The few published studies that have examined agroecosystem-scale functions in diversified cropping systems designed to promote linkages between $\mathrm{C}, \mathrm{N}$ and $\mathrm{P}$ cycles are promising. In these systems, productivity was maintained while nutrient balances were improved and internal nutrient reserves increased (Clark and others 1998; Drinkwater and others 1998; Blake and others 2000; Gregorich and others 2001). A greater proportion of total N inputs was accounted for, either as harvested exports or as $\mathrm{N}$ stored in the soil, in diversified rotations using low $\mathrm{C}: \mathrm{N}$ residues as $\mathrm{N}$ sources compared to simplified rotations managed with $\mathrm{F}_{\mathrm{i}}(\mathrm{Clark}$ and others 1998; Drinkwater and others 1998). Long-term studies also indicate that P-use by plants was much more efficient if $\mathrm{P}$ was applied in balance with $\mathrm{C}$ availability (Blake and others 2000) or when diversified rotations were used to increase the proportion of fertilizer $\mathrm{P}$ in biologicallymediated pools (Bunemann and others 2004b). When nutrient sources are manipulated, a smaller proportion of the nutrients added as organic residues or apatite is taken up by the crop however, a greater proportion is retained in various soil pools and is available to the crop in subsequent years (Azam and others 1985; Ladd and Amato 1986; Hodge and others 1999; Bundy and others 2001). These studies suggest that a nutrient management strategy based on a broader range of ecosystem processes is worth further investigation. They also demonstrate that nutrient mass balance and storage various soil reservoirs must be considered in conjunction with the current 
approach of estimating only the proportion of $F_{i}$ harvested as crop yield to accurately judge the efficacy of added nutrients.

While this kind of information is limited, there are numerous examples of research that targets a single process either in natural or managed ecosystems that could contribute to an integrated strategy for nutrient management. Our discussion will focus on three areas with the greatest potential for contributing to this approach: 1) increased plant biodiversity, 2) plantmicrobial interactions, and 3) microbially-mediated processes.

Using plant diversity to restore ecosystem functions

Efficient use of plant diversity to restore ecosystem functions will entail a more sophisticated approach than simply reinstating traditional rotations. Plants and their associated microbes regulate myriad processes which ultimately control ecosystem fluxes of $\mathrm{C}, \mathrm{N}$ and $\mathrm{P}$ (Wedin and Tilman 1990; Hooper and Vitousek 1997; Eviner and Chapin III 2001; Fierer and others 2001). Intentional management of plant diversity based on the capacity of a species to contribute to ecosystem processes will help restore desired agroecosystem functions, and can increase yields in systems where fertilizers are currently under applied (Drinkwater 1999; Snapp and Silim 2002; Vance and others 2003). Indeed, the potential for a single plant species to significantly influence ecosystem function is large in agroecosystems since single species effects tend to be more pronounced in ecosystems with limited biodiversity (Hector and others 1999; Chapin and others 2000), particularly when a missing functional group is added (Naeem and Li 1997). Plant species diversity can be increased either by introducing additional cash crops or non-cash crops such as cover crops or intercrops selected to serve specific ecosystem functions (non-cash crops will hereafter be referred to as accessory crops).

The most commonly identified functional roles used in classifying accessory crops are those relating to phenology (summer/winter annuals, perennial), productive potential, plant architecture and the nature of symbiont requirements ( $\mathrm{N}$-fixing, non-N-fixing). Plant species characteristics such as litter biochemistry, root exudate composition, fine root turnover and the characteristics of the rhizosphere environment also influence a variety of processes that control $\mathrm{C}, \mathrm{N}$ and $\mathrm{P}$ cycling. Significant plant species effects have been documented for decomposition dynamics and net mineralization of $\mathrm{N}$ and P (Wedin and Tilman 1990; Fierer and others 2001), aggregate formation (Angers and Mehuys 1989; Haynes and Beare 1997), ability to access nutrients such as Ca, Mg and P from mineral sources (Marschner and Dell 1994; Johnson and others 1997; Kamh and others 1999) and microbial community composition (Kennedy 1999; Burke and others 2002; Kent and Triplett 2002) and function (Cheng and others 2003).

Replacing bare fallows with appropriate cover crops should be a top priority of nutrient management programs. In a meta-analysis of the literature showed that cover cropping reduced nitrate leaching by an average of $70 \%$ without incurring any sacrifice in yield compared to conventional rotations where gaps between crops were maintained as bare fallows (Tonitto and others 2004). While the potential for reducing nitrate leaching has been determined under a variety of environments, other impacts have received limited attention. Bunemann and others (2004a) showed that including crotelaria (Crotalaria grahmiana) in rotation with maize shifts $50 \%$ more $\mathrm{P}$ fertilizer into the microbial biomass compared to continuous maize. Some recent work has screened cover crop species based on root architecture and root growth rates to identify species with the greatest potential for scavenging nitrate that had leached below the cash crop root zone (Thorup-Kristensen 2001). Depending on the biochemical composition, the additional litter from these plants remains in the ecosystem and enhances internal $\mathrm{N}$ and $\mathrm{P}$ supply through additions to labile SOM pools such as particulate organic matter which are decomposed during 
subsequent growing seasons (Ladd and Amato 1986; Puget and Drinkwater 2001) while also contributing to humified pools with much longer turnover times. Altering the timing of labile $\mathrm{C}$ inputs from root exudation may have cascading effects on the microorganisms that regulate internal cycling processes and increase the conversion of $\mathrm{C}$ to microbial biomass (Anderson and Domsch 1990; Jans-Hammermeister and others 1998).

Selecting plant species for their ability to contribution to $\mathrm{P}$ availability is an exciting possibility that is being studied in tropical systems where $\mathrm{P}$ is often the major limiting nutrient. In pot experiments aimed at screening a large number of legume species for $\mathrm{P}$ cycling attributes lupin (Lupinus albus) and pigeonpea (Cajanus cajan) were the most effective legumes at 1) excreting organic acids and 2) enhancing P bioavailability for subsequent maize crops (Kamh and others 1999). Long term studies comparing grass vs legume-grass pasture systems also show larger reservoirs of labile organic P (Oberson and others 2001).

To assess the full value of accessory crops, contributions to other ecosystem functions such as enhanced disease suppression (Abawi and Widmer 2000), reduced weed competition and herbicide requirements (Gallandt and others 1999) and pesticide reductions due to beneficial arthropod communities (Lewis and others 1997) need to be considered. Restoration of ecosystem function through plant-microbial interactions

Agriculture has a long history of research aimed at understanding how to improve the effectiveness of root symbionts such as rhizobia and mycorrhizae (Kiers et al., 2002). Plantmycorrhizal associations are the major mechanism for P uptake in over $80 \%$ of plant species. In low fertility soils they also enhance uptake of $\mathrm{NO}_{3}{ }^{-}$and $\mathrm{NH}_{4}{ }^{+}$(Marschner and Dell 1994). Ectomycorrhizal symbiosis in perennial horticultural systems and rhizobia-legume symbioses are routinely promoted (Graham and Eissenstat 1994; Peoples and others 1995) yet in general, agricultural production practices appear to have inadvertently reduced diversity, function and efficiency in these symbioses, shifting a mutalistic, beneficial association to almost a parasitic relationship in some instances (Johnson and others 1997; Daniell and others 1998; Denison and others 2003). A promising approach based on understanding how natural selection regulates changes in mutualistic interactions has been proposed ((Johnson and others 1997; Kiers and others 2002; Denison and others 2003). Knowledge of basic evolutionary processes could be used to develop agricultural management practices that favor the most effective symbionts.

Management of the exchange of $\mathrm{C}$ from primary producers to decomposers in return for nutrients has not been attempted in agroecosystems, despite the opportunity afforded by the rhizosphere as the site of this mutual co-dependancy between decomposers and plants (Wall and Moore 1999; Naeem and others 2000). Plants can stimulate decomposition of organic substrates by supplying labile $\mathrm{C}$ to decomposers in the rhizosphere (Clarholm 1985; Hamilton and Frank 2001; Cheng and others 2003). The identity of the SOM pools accessed through this mechanism remains unknown however, decomposition of chemically recalcitrant substrates is accelerated in the rhizosphere (Siciliano and others 2003). The rate of decomposition and N-mineralization varies with plant species (Cheng and others 2003), rhizosphere community composition (Clarholm 1985; Ferris and others 1998; Chen and Ferris 1999) and nutrient availability (Tate III and others 1991; Liljeroth and others 1994). Net mineralization does not simply depend on a surplus of nutrients relative to $\mathrm{C}$ during decomposition but is enhanced by the involvement of secondary consumers feeding on the primary decomposers due to differences in the stoichiometry between the two trophic levels (Clarholm 1985; Ferris and others 1998; Chen and Ferris 1999). This trophic cascade provides a mechanism for the primary producers to influence nutrient mineralization analogous to the so-called "microbial loop" in aquatic ecosystems where 
primary producers often increase excretion of soluble $\mathrm{C}$ under nutrient limiting conditions (Berman and Dubinsky 1999; Elser and Urabe 1999). Under these conditions, food web structure is a significant regulator of nutrient availability and can determine whether the primary producers are $\mathrm{N}$ or P limited (Elser and Urabe 1999) There is growing evidence that plants can influence the rate of net $\mathrm{N}$ mineralization through this mechanism, based on their need for nutrients by modifying the amount of soluble $\mathrm{C}$ excreted into the rhizosphere (Hamilton and Frank 2001).

Greater reliance on plant-mediated mineralization for nutrient acquisition in agroecosystems would reduce the potential for nutrient losses due to the tight coupling between net mineralization of $\mathrm{N}$ and $\mathrm{P}$ and plant uptake in the rhizosphere. Inorganic nutrient pools can be extremely small in ecosystems while high rates of net primary productivity (NPP) are maintained if $\mathrm{N}$-mineralization and plant assimilation are spatially and temporally connected in this manner (cf. Jackson and others 1988). To effectively manage this process, many questions remain to be answered. In particular, understanding which SOM pools are being accessed by plant-mediated decomposition will be key as will the development of strategies to manage agroecosystems to increase these reservoirs while minimizing net mineralization in the absence of plants. Other aspects such as food-web structure could also be influenced by management to optimize this process.

Microbially-mediated processes

Microorganisms represent a substantial portion of the standing biomass in terrestrial ecosystems and contribute to the regulation of $\mathrm{C}$ sequestration, $\mathrm{N}$ availability and losses, and $\mathrm{P}$ dynamics. The amount of $\mathrm{N}$ and $\mathrm{P}$ in soil prokaryotes is nearly equal to the amount in terrestrial plants (Whitman and others 1998). For cultivated systems, the $\mathrm{N}$ and $\mathrm{P}$ in soil prokaryotes in the top meter of soil is estimated to average $630 \mathrm{~kg} \mathrm{ha}^{-1}$ and $60 \mathrm{~kg} \mathrm{ha}^{-1}$, respectively (Whitman and others 1998). Microbial biomass $\mathrm{P}$ turnover is rapid, approximately twice as fast as $\mathrm{C}$ (Kouno and others 2002), suggesting the potential for microbial $\mathrm{P}$ pools to support plant $\mathrm{P}$ requirements may have been markedly underestimated. The size and physiological state of the standing microbial biomass is influenced by management practices, including rotational diversity (Anderson and Domsch 1990), tillage (Holland and Coleman 1987) and the quality and quantity of C inputs to the soil (Wander and Traina 1996; Lundquist and others 1999; Fliessbach and Mader 2000). We see exciting possibilities for influencing microbially-mediated processes. Increased knowledge of the environmental physiology of soil microbes would greatly enhance our understanding of the relationship between management and microbial community function and support intentional manipulation of microbial functional groups in favor of desired outcomes.

During decomposition, microbial community composition and metabolic status determine the balance between $\mathrm{C}$ respired and $\mathrm{C}$ assimilated into biomass. Management strategies such as reduced tillage foster increased abundance of fungal decomposers and can lead to increased $\mathrm{C}$ retention (Holland and Coleman 1987). Heterotrophs in soils with greater plant species diversity or greater abundance of $\mathrm{C}$ relative to $\mathrm{N}$ appear to convert a greater proportion of metabolized $\mathrm{C}$ to biomass (Aoyama and others 2000; Fliessbach and others 2000).

The new molecular tools that make it possible to characterize abundance and activity of microbial functional groups open up new possibilities for intentional management of the microbial community to enhance $\mathrm{N}$ retention. Cavigelli and Robertson (Cavigelli and Robertson $2000 ; 2001)$ discovered that denitrifiers from an agricultural soil were more sensitive to $\mathrm{O}_{2}$ levels and produced a greater proportion of $\mathrm{N}_{2} \mathrm{O}$ compared to denitrifiers from an early successional plant community. Denitrifier community composition influenced both the rate of denitrification 
and the proportion of $\mathrm{N}_{2} \mathrm{O}$ to $\mathrm{N}_{2}$ produced. A second anaerobic $\mathrm{NO}_{3}{ }^{-}$pathway, dissimilatory nitrate reduction to ammonium (DNRA), occurs in a variety of unmanaged terrestrial ecosystems (Silver and others 2001) and could also be manipulated to enhance $\mathrm{N}$ conservation. Previously this process was thought to be limited to extremely anaerobic, C-rich environments such as sewage sludge and submerged sediments (Maier and others 2000). Silver and others (2001) reported average rates of DNRA were 3-fold greater than denitrification in humid tropical forest soils and concluded that the resulting reduction in $\mathrm{NO}_{3}$ availability to denitrifiers and leaching may contribute to $\mathrm{N}$ conservation in these ecosystems. The presence of microbes capable of DNRA in agricultural systems has yet to be determined, but there is no reason to expect this process to be excluded from managed ecosystems. Agricultural soils with management-induced increases in labile-C pools have a greater $\mathrm{NH}_{4}: \mathrm{NO}_{3}$ ratio compared to soils where $\mathrm{C}$ is less abundant (Drinkwater and others 1995) suggesting DNRA may be an important N-conserving process in agroecosystems that could be enhanced through management of appropriate SOC pools.

Microorganisms access $\mathrm{P}$ through several mechanisms that ultimately lead to increased $\mathrm{P}$ availability for primary producers (Illmer and others 1995; Oberson and others 2001). Direct excretion of phosphatase enzymes is an important mechanism for releasing $\mathrm{P}$ from recalcitrant organic forms such as phytic acid. Sparingly soluble $\mathrm{P}$ is made available through organic acid excretion, such as occurs in the soil fungus Penicillium radicum isolated from a low-P rhizosphere of unfertilized wheat (Whitelaw and others 1999). In this system, $\mathrm{PO}_{4}{ }^{-}$solubilization from insoluble or sparingly soluble complexes with metals was related to titratable acidity and gluconic acid concentration. Organic acid excretion not only alters $\mathrm{pH}$, but also may chelate $\mathrm{Al}^{+3}$ or other cations directly, further enhancing the solubilization of $\mathrm{PO}_{4}^{-}$(Erich and others 2002; Laboski and Lamb 2003). An incubation study investigating the microbial community structure in legume-maize cropping system, found that fungal and gram negative bacteria abundance tracked was correlated with the organic P pool, and that the major driver determining the size of the labile organic P pool was crop rotation and the presence of plant residues with high soluble carbon content (Bunemann and others 2004a).

\section{Plant adaptation to ecosystem-based nutrient management}

In the last half-century plant breeding has occurred almost entirely under management regimes that include fumigated soils with luxurious additions of nutrients and sufficient water (Boyer 1982) and has produced modern hybrids well-adapted to a microbially deficient soil environment with abundant resources. This strategy of reducing environmental variation by providing ample resources reduces gene by environment interaction, and enhances the power of selection for specific traits (Banziger and Lafitte 1997). However, it has potentially selected against traits that allow plants to maintain high NPP and yeilds under non-saturating nutrient conditions (Jackson and Koch 1997) and has contributed to the need for surplus nutrient additions.

The impacts of conventional plant selection practices on belowground characteristics has rarely been investigated, although interest in this area is growing. In lettuce, comparison of wild genotypes and modern cultivars demonstrated a marked decrease in root system nutrient scavenging ability due to altered root architecture and reduced plasticity (Jackson 1995). Cultivar effects on root-associated microorganisms have been found more often than not, and there is now considerable evidence that rhizosphere community composition varies at the cultivar level in agroecosystems (Siciliano and others 1998; Dalmastri and others 1999; Germida and Siciliano 2001; Briones and others 2002). Modern wheat varieties have rhizosphere communities distinct 
from pre-industrial varieties (Germida and Siciliano 2001). In most cases, the functional significance of these differences in plant-associated microbial communities is not known. A notable exception is the case of traditional versus modern rice cultivars where plant-induced species differences in rhizoplane ammonium-oxidizing bacteria appear to account for the greater nitrification rates in the rhizosphere of the modern variety (Briones and others 2002; 2003). Clearly, plant selection for high yields has had unintended cascading effects on the associated microorganisms and biogeochemical functions.

These examples demonstrate that plants do not exist as single organisms, but are more accurately viewed as a consortium consisting of a primary producer and many species of associated microbes. We see many opportunities for plant breeding to enhance plant-microbialnutrient interactions in ways that contribute to restored ecosystem functions through some of the mechanisms we have highlighted in this paper. Crop breeding programs should select for welladapted consortia that can achieve necessary yields by accessing nutrient reservoirs less susceptible to loss. Criteria for selection of cash crops should be expanded to include contributions to ecosystem function. For example, crop species with unique ecosystem functions such as N-fixers should be selected under conditions that will enhance these abilities while optimizing yields. On the other hand, accessory crops can be selected to enhance their capability to provide ecosystem services while filling specific niches in space and time that are compatible with cash crop production.

There are a few examples of breeding programs intentionally aimed at improving yields under conditions where nutrients are not saturating. A marked increase in $\mathrm{N}$ derived from BNF and yield adaptation to low-input, $\mathrm{N}$-limited cropping systems was recently achieved in the Brazilian soybean breeding program (Alves and others 2003). More modest success was achieved by the seminal collaboration of a breeder, microbiologist and plant physiologist to improve BNF in alfalfa (Barnes and others 1984; Jessen and others 1988). Research to improve yield potential of cereal grains in low nutrient environments has been sporadic, with mixed results until a recent concerted effort showed that it is possible to improve yields of wheat and corn in low input environments (Banziger and Cooper 2001).

\section{Conclusions}

While the concept of sustainability as a goal has become widely accepted, the dominant agricultural paradigm still considers high yields and reduced environmental impacts to be in conflict with one another (Keller and Brummer 2002). The requirement for nutrient saturation in agriculture will not be easy to overcome given the economic constraints imposed on productionoriented farming systems. Nutrient surpluses in agroecosystems, and hence environmental losses can be reduced through intentional management of intrinsic ecosystem processes. Our approach shifts the emphasis of nutrient management away from soluble, inorganic plant-available pools to organic and mineral reservoirs that can be accessed through microbially- and plant-mediated processes. The goal of nutrient management under this framework would be to balance nutrient budgets as much as possible while maintaining these reservoirs. Management practices that increase the sink capacity of the ecosystem in ways that contribute to reduced needs for surplus additions should be emphasized in conjunction with breeding for cultivars and their associated microorganisms that do not require surplus additions of soluble nutrients. Understanding how plants alter microbial community structure and function to facilitate access to organic and mineral reservoirs (i.e. decomposition and assimilation of $\mathrm{N}$ and $\mathrm{P}$ from recalcitrant organic polymers, $\mathrm{P}$ mobilization from mineral reservoirs) will be an important consideration for cash crops. On the other hand, for accessory crops, understanding assimilatory processes that compete with P- 
geochemical sinks and $\mathrm{N}$ loss pathways will be particularly important.

The critical question remains, what productivity levels can be supported by this approach? We do not believe that this question can be fully answered based on available research. Levels of NPP comparable to those achieved in high yielding agricultural systems occur in unmanaged ecosystems (Zak and others 1994) and monocultures composed of weedy species (Abul Fatih and others 1979). Perhaps a more appropriate question is: What proportion of annual NPP would need to be allocated to provide internal ecosystem services while still meeting the goals for harvested exports? This will depend on ecosystem state factors such as climate, topography and parent soil material, as well as socioeconomic constraints. Many climates with sufficient water and a long growing season support very high annual NPP. These conditions increase the potential for a portion of the NPP to be devoted to the provision of ecosystem functions. In contrast, areas with severe water, light or temperature limitations such as the arid tropics or cold temperate zones will likely require strategic inputs of inorganic nutrients. It follows that an additional requirement for the success of this approach will be to match production systems with the strengths and limitations of the environment.

\section{Acknowledgments}

We thank Mark David, Valerie Eviner, Jørgen Olesen and David Wolfe for helpful comments on an earlier draft. We also thank the many agricultural professionals, including farmers, who have shared their real world perspective with us over the years. This work was supported by NSF- BE/CBC \#0216316 to LED and others. 


\section{Figure legends}

Figure 1. Refinement of $\mathrm{N}$ fertilizer recommendations for New York during the past 50 years by 5 -year increments (1). Initially, recommended amounts of $\mathrm{N}$ fertilizer were based simply on whether or not animal manure would be applied. By the 1980's fertilizer recommendation tables included history of animal manure application, cropping history, and soil type resulting in $>100$ different fertilizer rates (i.e. in 1985 there were 5 soil types x 10 cropping histories x 3 manure rates). Data from Cornell Cooperative Extension 1950-2003.

Figure 2. Fate of $\mathrm{N}$ relative to $\mathrm{N}$ additions across a range of ecosystems. (a) Nitrate leaching losses relative to $\mathrm{N}$ additions in annual cropping systems, forests and a pasture (Jemison and Fox 1994; McCracken and others 1994; Randall and Iragavarapu 1995; Brandi-Dohrn and others 1997; Kanwar and others 1997; Randall and others 1997; Fenn and others 1998; Staver and Brinsfield 1998; Steinheimer and others 1998). Linear regression and 95\% confidence intervals for annual rotations without cover crops is shown. The graph includes leaching studies that met the following criteria: 1) studies conducted in North America in annual rotations that included corn 2) at least 2 years of data from treatments that had been in place for at least one year before data collection began 3 ) year-round collection of leachate from below the root zone and 4) medium soil textures (clay loam or silt loam to silty-clay loam). (b) Fate of fertilizer-derived N applied to wheat as a single application of $250 \mathrm{~kg} \mathrm{ha}^{-1}$ compared to split applications totaling 180 $\mathrm{kg} \mathrm{ha}^{-1}$. Modified after Matson and others 1998 with additional data provided by the authors to LED.

Figure 3. Conceptual model for the current nutrient management strategy (blue background) compared to our proposed ecosystem-based framework (green background). Arrow colors indicate dominant elemental fluxes as follows: N (blue), P (green), N\&P (blue-green) and C (grey). (a) Under current practices, $\mathrm{N}$ and $\mathrm{P}$ are added primarily as soluble, plant available forms. The majority of these inputs are lost either through leaching (mainly N, some P), gaseous losses $(\mathrm{N})$, P-fixation into occluded pools, and erosion (N and P). Soluble pools are relatively large while microbial biomass and SOM pools are reduced. (b) Shifting the focus to management of pools with longer MRT's including the range of SOM pools and sparingly-soluble $\mathrm{P}$ would reduce standing pools of soluble inorganic $\mathrm{N}$ and $\mathrm{P}$, increase microbially-mediated assimilation and mineralization and reduce nutrient losses. Nutrient sources are diversified (BNF, organic residues, sparingly soluble rock $\mathrm{PO}_{4}{ }^{-}$and reduced amounts of soluble $\mathrm{F}_{\mathrm{i}}$ ). In both cases, labile $\mathrm{C}$ is exchanged to access soil reservoirs, however this mechanism is actively promoted in our ecologically-driven framework. 
Drinkwater \& Snapp-Page 12

\section{Literature Cited}

Abawi GS and Widmer TL. 2000. Impact of soil health management practices on soilborne pathogens, nematodes and root diseases of vegetable crops. Applied Soil Ecology 15:3747.

Aber JD, Nadelhoffer KJ, Steudler P and Melillo JM. 1989. Nitrogen saturation in northern forest ecosystems. Bioscience 39:378-386.

Abul Fatih HA, Bazzaz FA and Hunt R. 1979. The biology of Ambrosia trifida 3. growth and biomass allocation. New Phytologist 83:829-838.

Agren GI and Bosatta E. 1988. Nitrogen saturation of terrestrial ecosystems. Environmental Pollution 54:185-198.

Altieri MA. 1989. Agroecology: a new research and development paradigm for world agriculture. Agriculture Ecosystems and Environment 27:37-46.

Alves BJR, Boddey RM and Urquiaga S. 2003. The success of BNF in soybean in Brazil. Plant and Soil 252:1-9.

Anderson TH and Domsch KH. 1990. Application of eco-physiological quotients $\left(q \mathrm{CO}_{2}\right.$ and $\left.q \mathrm{D}\right)$ on microbial biomasses from soils of different cropping histories. Soil Biology Biochemistry 22:251-255.

Andrews WB. 1947. The response of crops and soils to fertilizers and manures. W.B. Andrews, State College, Miss.

Angers DA and Mehuys GR. 1989. Effects of cropping on carbohydrate content and water-stable aggregation of a clay soil. Canadian journal of soil science 69:373-380.

Aoyama M, Angers DA, N'Dayegamiye A and Bissonnette N. 2000. Metabolism of ${ }^{13} \mathrm{C}$-labeled glucose in aggregates from soils with manure application. Soil Biology and Biochemistry 32:295-300.

Aref S and Wander MM. 1997. Long-term trends of corn yield and soil organic matter in different crop sequences and soil fertility treatments on the morrow plots. Advances in Agronomy 62:153-197.

Auclair AN. 1976. Ecological factors in the development of intensive management ecosystems in the midwestern USA. Ecology. 57:431-444.

Azam F, Malik KA and Sajjad MI. 1985. Transformations in soil and availability to plants of ${ }^{15} \mathrm{~N}$ applied as inorganic fertilizer and legume residues. Plant and Soil 86:3-13.

Banziger M and Cooper M. 2001. Breeding for low input conditions and consequences for participatory plant breeding: examples from tropical maize and wheat. Euphytica 122:503519.

Banziger M and Lafitte HR. 1997. Efficiency of secondary traits for improving maize for lownitrogen target environments. Crop Science 37:1110-1117.

Barnes DK, Heichel GH, Vance CP and Ellis WR. 1984. A multiple-trait breeding program for improving the symbiosis for $\mathrm{N}_{2}$ fixation between Medicago sativa and Rhizobium meliloti. Plant and Soil 82:303-314.

Bear FE. 1926. The coming need for higher yields. Pages 5-10 in Association NF, editor. Soil Fertility Conferences in the Northern States.

Berman FI and Dubinsky Z. 1999. Balanced growth and aquatic plants: Myth or reality? Phytoplankton use the imbalance between carbon assimilation and biomass production to their strategic advantage. Bioscience 49:29-37.

Blake L, Mercik S, Koerschens M, Moskal S, Poulton PR, Goulding KWT, Weigel A and Powlson DS. 2000. Phosphorus content in soil, uptake by plants and balance in three European long-term field experiments. Nutrient Cycling in Agroecosystems 56:263-275.

Bolland MDA and Gilkes RJ. 1998. The chemistry and agronomic effectiveness of phosphate 
fertilizers. Pages 139-163 in Rengel Z, editor. Nutrient Use in Crop Production. The Haworth Press, Inc., NY, NY.

Boyer JS. 1982. Plant productivity and environment. Science 218:443-448.

Brandi-Dohrn FM, Dick RP, Hess M, Kauffman SM, Hemphill DD, Jr. and Selker JS. 1997. Nitrate leaching under a cereal rye cover crop. Journal of Environmental Quality 26:181188.

Bray RH and Kurtz LT. 1945. Determination of total, organic and available forms of phosphorus in soils. Soil Science 59:39-45.

Briones AM, Jr., Okabe S, Umemiya Y, Ramsing NB, Reichardt W and Okuyama H. 2002. Influence of different cultivars on populations of ammonia-oxidizing bacteria in the root environment of rice. Applied and Environmental Microbiology 68:3067-3075.

Briones AM, Jr., Okabe S, Umemiya Y, Ramsing NB, Reichardt W and Okuyama H. 2003. Ammonia-oxidizing bacteria on root biofilms and their possible contribution to $\mathrm{N}$ use efficiency of different rice cultivars. Plant and Soil 250:335-348.

Bundy LG, Andraski TW and Powell JM. 2001. Management practices effects on phosphorus losses in runoff in corn production systems. Journal of Environmental Quality 30:18221828.

Bunemann E, Bassio DA, Smithson PC, Frossard E and Oberson A. 2004a. Microbial community composition and substrate use in a highly weathered soil as affected by crop rotation and $\mathrm{P}$ fertilization. Soil Biology and Biochemistry 36:889-901.

Bunemann EK, Steinebrunner F, Smithson PC, Frossard E and Oberson A. 2004b. Phosphorus dynamics in a highly weathered soil as revealed by isotopic labeling techniques. Soil SSoil Science Society of America Journal 68:1645-1655.

Burke DJ, Hamerlynck EP and Hahn D. 2002. Interactions among plant species and microorganisms in salt marsh sediments. Applied and Environmental Microbiology 68:1157-1164.

Campbell C-A and Zentner R-P. 1993. Soil organic matter as influenced by crop rotations and fertilization. Soil Science Society of America Journal.

Carpenter SR, Caraco NF, Correll DL, Howarth RW, Sharpley AN and Smith VH. 1998. Nonpoint pollution of surface waters with phosphorus and nitrogen. Ecological Applications 8:559-568.

Carpenter SR and Cottingham KL. 1997. Resilience and restoration of lakes. Conservation Ecology [online] 1:2.

Cassman KG, Dobermann A and Walters DT. 2002. Agroecosystems, nitrogen-use efficiency, and nitrogen management. Ambio 31:132-140.

Cavigelli MA and Robertson GP. 2000. The functional significance of denitrifier community composition in a terrestrial ecosystem. Ecology 81:1402-1414.

Cavigelli MA and Robertson GP. 2001. Role of denitrifier diversity in rates of nitrous oxide consumption in a terrestrial ecosystem. Soil Biology and Biochemistry 33:297-310.

Chapin FS, III, Vitousek PM and Van Cleve K. 1986. The nature of nutrient limitation in plant communities. American Naturalist 127:48-58.

Chapin FS, III, Zavaleta ES, Eviner VT, Naylor RL, Vitousek PM, Reynolds HL, Hooper DU, Lavorel S, Sala OE, Hobbie SE, Mack MC and Diaz S. 2000. Consequences of changing biodiversity. Nature 405:234-242.

Chen J and Ferris H. 1999. The effects of nematode grazing on nitrogen mineralization during fungal decomposition of organic matter. Soil Biology and Biochemistry 31:1265-1279.

Cheng W, Johnson DW and Fu S. 2003. Rhizosphere effects on decomposition: controls of plant 
species, phenology, and fertilization. Soil Science Society of America Journal 67:14181427.

Cheng W, Zhang Q, Coleman DC, Carroll CR and Hoffman CA. 1996. Is available carbon limiting microbial respiration in the rhizosphere? Soil Biology and Biochemistry 28:12831288.

Clarholm M. 1985. Interactions of bacteria, protozoa and plants leading to mineralization of soil nitrogen. Soil Biology Biochemistry 17:181-187.

Clark MS, Horwath WR, Shennan C and Scow KM. 1998. Changes in soil chemical properties resulting from organic and low-input farming practices. Agronomy Journal 90:662-671.

Cornell Cooperative Extension . 1950-2003. Cornell Recommends for Field Crops. New York State College of Agriculture and Life Sciences, Ithaca, NY.

Crookes W, Sir. 1899. The wheat problem; based on remarks made in the presidential address to the British association at Bristol in 1898. G.P. Putnam's Sons, New York.

Dalmastri C, Chiarini L, Cantale C, Bevivino A and Tabacchioni S. 1999. Soil type and maize cultivar affect the genetic diversity of maize root-associated Burkholderia cepacia populations. Microbial Ecology 38:273-284.

Daniell TJ, Husband R, Fitter AH and Young JPW. 1998. Where have all the fungi gone? II. The diversity of Arbuscular mycorrhizal fungi is low in agricultural ecosystems. Journal of Experimental Botany 49:40.

David MB and Gentry LE. 2000. Anthropogenic inputs of nitrogen and phosphorus and riverine export for Illinois, USA. Journal of Environmental Quality 29:494-508.

Denison R-F, Kiers E-T and West S-A. 2003. Darwinian agriculture: When can humans find solutions beyond the reach of natural selection? Quarterly Review of Biology.

Drinkwater LE. 1999. Using plant species composition to restore soil quality and ecosystem function. Pages 37-46 in Olesen JE, Eltun R, Gooding MJ, Jensen ES and Kopke U, editors. Designing and testing crop rotations for organic farming, Tjele, Denmark.

Drinkwater LE, Letourneau DK, Workneh F, Van BAHC and Shennan C. 1995. Fundamental differences between conventional and organic tomato agroecosystems in California. Ecological Applications 5:1098-1112.

Drinkwater LE, Wagoner P and Sarrantonio M. 1998. Legume-based cropping systems have reduced carbon and nitrogen losses. Nature 396:262-265.

Ehler LE and Bottrell DG. 2000. The illusion of integrated pest management. Issues in Science and Technology [online] Spring 2000.

Elser JJ and Urabe J. 1999. The stoichiometry of consumer-driven nutrient recycling: theory, observations, and consequences. Ecology 80:735-751.

Erich MS, Fitzgerald CB and Porter GA. 2002. The effect of organic amendments on phosphorus chemistry in a potato cropping system. Agriculture Ecosystems and Environment 88:7988.

Eviner VT and Chapin III FS. 2001. Plant species provide vital ecosystem functions for sustainable agriculture, rangeland management and restoration. California Agriculture 55:54-59.

Fenn ME, Poth MA, Aber JD, Baron JS, Bormann BT, Johnson DW, Lemly AD, McNulty SG, Ryan DF and Stottlemyer R. 1998. Nitrogen excess in North American ecosystems: predisposing factors, ecosystem responses, and management strategies. Ecological Applications 8:706-733.

Ferris H, Venette RC, Van Der Meulen HR and Lau SS. 1998. Nitrogen mineralization by bacteria-feeding nematodes: verification and measurement. Plant and Soil 203:159-171. 
Fierer N, Schimel JP, Cates RG and Zou J. 2001. Influence of balsam poplar tannin fractions on carbon and nitrogen dynamics in Alaskan taiga floodplain soils. Soil Biology and Biochemistry 33:1827-1839.

Fliessbach A and Mader P. 2000. Microbial biomass and size-density fractions differ between soils of organic and conventional agricultural systems. Soil Biology and Biochemistry 32:757-768.

Fliessbach A, Mader P and Niggli U. 2000. Mineralization and microbial assimilation of ${ }^{14} \mathrm{C}$ labeled straw in soils of organic and conventional agricultural systems. Soil Biology and Biochemistry 32:1131-1139.

Gallandt ER, Liebman M and Huggins DR. 1999. Improving soil quality: Iiplications for weed management. Journal of Crop Production 2:95-121.

Galloway JN. 2000. Nitrogen mobilization in Asia. Nutrient Cycling in Agroecosystems 57:1-12.

Galloway JN and Cowling EB. 2002. Reactive nitrogen and the world: 200 Years of change. Ambio 31:64-71.

Germida JJ and Siciliano SD. 2001. Taxonomic diversity of bacteria associated with the roots of modern, recent and ancient wheat cultivars. Biology and Fertility of Soils 33:410-415.

Graham JH and Eissenstat DM. 1994. Host genotype and the formation and function of VA mycorrhizae. Plant and Soil 159:179-185.

Gregorich EG, Drury CF and Baldock JA. 2001. Changes in soil carbon under long-term maize in monoculture and legume-based rotation. Canadian journal of soil science 81:21-31.

Hambridge G. 1938. Soils and Men- a summary. Pages 1-44 in Soils and Men, Yearbook of Agriculture. United States Government Printing Office, Washington, D.C.

Hamilton EW, III and Frank DA. 2001. Can plants stimulate soil microbes and their own nutrient supply? Evidence from a grazing tolerant grass. Ecology 82:2397-2402.

Haynes RJ and Beare MH. 1997. Influence of six crop species on aggregate stability and some labile organic matter fractions. Soil Biology and Biochemistry 29:1647-1653.

Hector A, Schmid B, Beierkuhnlein C, Caldeira MC, Diemer M, Dimitrakopoulos PG, Finn JA, Freitas H, Giller PS, Good J, Harris R, Hogberg P, Huss DK, Joshi J, Jumpponen A, Korner C, Leadley PW, Loreau M, Minns A, Mulder C, O DG, Otway SJ, Pereira JS, Prinz A, Read DJ, Scherer LM, Schulze ED, Siamantziouras ASD, Spehn EM, Terry AC, Troumbis AY, Woodward FI, Yachi S and Lawton JH. 1999. Plant diversity and productivity experiments in European grasslands. Science 286:1123-1127.

Hodge A, Robinson D, Griffiths BS and Fitter AH. 1999. Nitrogen capture by plants grown in Nrich organic patches of contrasting size and strength. Journal of Experimental Botany 50:1243-1252.

Holland EA and Coleman DC. 1987. Litter placement effects on microbial and organic matter dynamics in an agroecosystem. Ecology 62:425-433.

Hooper DU and Vitousek PM. 1997. The effects of plant composition and diversity on ecosystem processes. Science 277:1302-1305.

Hopkins DP. 1945. Chemicals, humus, and the soil; a simple presentation of contemporary knowledge and opinions about fertilizers, manures and soil fertility. Faber and Faber Limited, London.

Howarth RW, Jensen H, Marino R and Postma H. 1995. Transport to and processing of phosphorus in near-shore and oceanic waters. Pages 323-345 in Tiessen H, editor. Phosphorus in the Global Environment. Wiley \& Sons, Chichester.

Illmer P, Barbato A and Schinner F. 1995. Solubilization of hardly-soluble AlPO 4 with Psolubilizing microorganisms. Soil Biology and Biochemistry 27:265-270. 
Jackson LE. 1995. Root architecture in cultivated and wild lettuce (Lactuca spp.). Plant Cell and Environment 18:885-894.

Jackson LE and Koch GW. 1997. The ecophysiology of crops and their wild relatives. Pages 3-37 in Jackson LE, editor. Ecology in agriculture. Academic Press Inc., San Diego, CA.

Jackson LE, Strauss RB, Firestone MK and Bartolome JW. 1988. Plant and soil nitrogen dynamics in California annual grassland. Plant and Soil 110:9-17.

Jans-Hammermeister DC, McGill WB and Izaurralde RC. 1998. Management of soil C by manipulation of microbial metabolism: daily vs. pulsed $\mathrm{C}$ additions. Pages 321-333 in Lal R, Kimble JM, Follett RF and Stewart BA, editors. Soil processes and the carbon cycle. CRC Press, Boca Raton, Fla.

Jemison JM, Jr. and Fox RH. 1994. Nitrate leaching from nitrogen-fertilized and manured corn measured with zero-tension pan lysimeters. Journal of Environmental Quality 23:337-343.

Jessen DL, Barnes DK and Vance CP. 1988. Bidirectional selection in alfalfa for activity of nodule nitrogen and carbon-assimilating enzymes. Crop Science 28:18-22.

Johnson NC, Graham JH and Smith FA. 1997. Functioning and mycorrhizal associations along the mutualism-parasitism continuum. New Phytologist 135:575-585.

Kamh M, Horst WJ, Amer F, Mostafa H and Maier P. 1999. Mobilization of soil and fertilizer phosphate by cover crops. Plant and Soil 211:19-27.

Kanwar RS, Colvin TS and Karlen DL. 1997. Ridge, moldboard, chisel, and no-till effects on tile water quality beneath two cropping systems (MISSING). Journal of Production Agriculture 10:227-234.

Keller DR and Brummer EC. 2002. Putting Food Production in Context: Toward a Postmechanistic Agricultural Ethic. Bioscience 52:264-271.

Kennedy AC. 1999. Bacterial diversity in agroecosystems. Agriculture Ecosystems and Environment 74:65-76.

Kent AD and Triplett EW. 2002. Microbial communities and their interactions in soil and rhizosphere ecosystems. Pages 211-236 in Ornston LN, Balows A and Gottesman-Susan E, editors. Annual Review of Microbiology. Annual Reviews, 4139 El Camino Way, Palo Alto, CA, 94303-0139, USA.

Kiers ET, West SA and Denison RF. 2002. Mediating mutualisms: Farm management practices and evolutionary changes in symbiont co-operation. Journal of Applied Ecology 39:745754.

Koch B, Worm J, Jensen LE, Hojberg O and Nybroe O. 2001. Carbon limitation induces sigmaSdependent gene expression in Pseudomonas fluorescens in soil. Applied and Environmental Microbiology 67:3363-3370.

Kouno K, Wu J and Brookes PC. 2002. Turnover of biomass C and P in soil following incorporation of glucose or ryegrass. Soil Biology and Biochemistry 34:617-622.

Laboski CAM and Lamb JA. 2003. Changes in soil test phosphorus concentration after application of manure or fertilizer. Soil Science Society of America Journal 67:544-554.

Ladd JN and Amato M. 1986. The fate of nitrogen from legume and fertilizer sources in soils successively cropped with wheat under field conditions. Soil Biology Biochemistry 18:417-425.

Lewis WJ, Van LJC, Phatak SC and Tumlinson JH, III. 1997. A total system approach to sustainable pest management. Proceedings of the National Academy of Sciences of the United States of America 94:12243-12248.

Liebman M and Gallandt E-R. 1997. Many little hammers: Ecological management of crop-weed interactions. 
Liljeroth E, Kuikman P and Van Veen JA. 1994. Carbon translocation to the rhizosphere of maize and wheat and influence on the turnover of native soil organic matter at different soil nitrogen levels. Plant and Soil 161:233-240.

Lowrance R. 1992. Groundwater Nitrate and Denitrification in a Coastal Plain Riparian Forest. Journal of Environmental Quality 21:401-405.

Lowrance R, Stinner BR and House GJ. 1984. Agricultural Ecosystems: Unifying Concepts. John Wiley \& Sons, New York.

Lundquist EJ, Jackson LE, Scow KM and Hsu C. 1999. Changes in microbial biomass and community composition, and soil carbon and nitrogen pools after incorporation of rye into three California agricultural soils. Soil Biology and Biochemistry 31:221-236.

Mackown C-T and Sutton T-G. 1997. Recovery of fertilizer nitrogen applied to burley tobacco. Agronomy Journal.

Magdoff FR, Ross DJ and Amadon J. 1984. A soil test for nitrogen availability to corn (Zea mays). Soil Science Society of America Journal 48:1301-1304.

Maier RM, Pepper IL and Gerba GP. 2000. Environmental microbiology. Academic Press, San Diego.

Marschner H and Dell B. 1994. Nutrient uptake in mycorrhizal symbiosis. Plant and Soil 159:89102.

Matson PA, Naylor R and Ortiz MI. 1998. Integration of environmental, agronomic, and economic aspects of fertilizer management. Science 280:112-115.

Matson PA, Parton WJ, Power AG and Swift MJ. 1997. Agricultural intensification and ecosystem properties. Science 277:504-509.

McCracken DV, Smith MS, Grove JH, MacKown CT and Blevins RL. 1994. Nitrate leaching as influenced by cover cropping and nitrogen source. Soil Science Society of America Journal 58:1476-1483.

Mitsch WJ, Day JW, Jr., Gilliam JW, Groffman PM, Hey DL, Randall GW and Wang N. 2001. Reducing nitrogen loading to the Gulf of Mexico from the Mississippi River Basin: Strategies to counter a persistent ecological problem. Bioscience 51:373-388.

Naeem S, Hahn DR and Schuurman G. 2000. Producer-decomposer co-dependency influences biodiversity effects. Nature 403:762-764.

Naeem S and Li S. 1997. Biodiversity enhances ecosystem reliability. Nature 390:507-509.

Oberson A, Friesen DK, Rao IM, Buhler S and Frossard E. 2001. Phosphorus transformations in an oxisol under contrasting land-use systems: the role of the soil microbial biomass. Plant and Soil 237:197-210.

Olsen SR, Cole CV, Watanabe FS and Dean LA. 1954. Estimate of available phosphorus in soils by extraction with sodium bicarbonate. USDA Circ. 939 USDA, Washington D.C.

Peoples MB, Ladha JK and Herridge DF. 1995. Enhancing legume N2 fixation through plant and soil management. Plant and Soil 174:83-101.

Pimentel D, McLaughlin L, Zepp A, Lakitan B, Kraus T, Kleinman P, Vancini F, Roach WJ, Graap E, Keeton WS and Selig G. 1991. Environmental and economic effects of reducing pesticide use: a substantial reduction in pesticides might increase food costs only slightly. Bioscience 41:402-409.

Puget P and Drinkwater LE. 2001. Short-term dynamics of root- and shoot-derived carbon from a leguminous green manure. Soil Science Society of America Journal 65:771-779.

Randall GW, Huggins DR, Russelle MP, Fuchs DJ, Nelson WW and Anderson JL. 1997. Nitrate losses through subsurface tile drainage in conservation reserve program, alfalfa, and row crop systems. Journal of Environmental Quality 26:1240-1247. 
Randall GW and Iragavarapu TK. 1995. Impact of long-term tillage systems for continuous corn on nitrate leaching to tile drainage. Journal of Environmental Quality 24:360-366.

Rouatt JW, Katznelson H and Payne TMB. 1960. Statistical evaluation of rhizosphere effect. Soil Science Society of America Proceedings 24:271-273.

Schreiner O and Anderson MS. 1938. Determining the fertilizer requirements of soils. Pages 469486 in Soils and Men, Yearbook of Agriculture. United States Department of Agriculture, Washington, D.C.

Siciliano SD, Germida JJ, Banks K and Greer CW. 2003. Changes in microbial community composition and function during a polyaromatic hydrocarbon phytoremediation field trial. Applied and Environmental Microbiology 69:483-489.

Siciliano SD, Theoret CM, De FJR, Hucl PJ and Germida JJ. 1998. Differences in the microbial communities associated with the roots of different cultivars of canola and wheat. Canadian Journal of Microbiology 44:844-851.

Silver WL, Herman DJ and Firestone MK. 2001. Dissimilatory nitrate reduction to ammonium in upland tropical forest soils. Ecology 82:2410-2416.

Smith MS and Tiedje JM. 1979. The Effect of Roots on Soil Denitrification. Soil Science Society of America Journal 43.

Snapp SS and Silim SN. 2002. Farmer preferences and legume intensification for low nutrient environments. Plant and Soil 245:181-192.

Staver KW and Brinsfield RB. 1998. Using cereal grain winter cover crops to reduce groundwater nitrate contamination in the mid-Atlantic coastal plain. Journal of Soil and Water Conservation 53:230-240.

Steinheimer T-R, Scoggin K-D and Kramer L-A. 1998. Agricultural chemical movement through a field-size watershed in Iowa: Surface hydrology and nitrate losses in discharge. Environmental Science and Technology.

Stevenson CK and Baldwin CS. 1969. Effect of time and method of nitrogen application and source of nitrogen on the yield and nitrogen content of corn (Zea mays). Agronomy Journal 61:381-384.

Tate III RL, Parmelee RW, Ehrenfeld JG and O'Reilly L. 1991. Nitrogen mineralization: root and microbial interactions in pitch pine microcosms. Soil Science Society of America Journal 55:1004-1008.

Tilman D. 1999. Global environmental impacts of agricultural expansion: The need for sustainable and efficient practices. Proceedings of the National Academy of Sciences of the United States of America 96:5995-6000.

Tisdale SL, Nelson WL and Beaton JD. 1993. Soil fertility and fertilizers, 5 edition. Collier Macmillan Publishers, New York.

Tonitto C, David MB and Drinkwater LE. 2004. Response of crop yields and soil N to diversified rotations: a meta-analysis. Agriculture Ecosystems and Environment In press.

Tran TS, Giroux M and Cescas MP. 1997. Effect of $\mathrm{N}$ rate and application methods on ${ }^{15} \mathrm{~N}-$ labelled fertilizer use by corn. Canadian journal of soil science.

Tyrrell T. 1999. The relative influences of nitrogen and phosphorus on oceanic primary production. Nature 400:525-531.

Van der Molen DT, Breeuwsma A and Boers PCM. 1998. Agricultural nutrient losses to surface water in the Netherlands: impact, strategies, and perspectives. Journal of Environmental Quality 27:4-11.

van Elsas JD and van Overbeek LS. 1996. Bacterial responses to soil stimuli. Pages 55-79 in Kjelleberg S, editor. Starvation in bacteria. Plenum Press, New York. 
Vance CP, Uhde SC and Allan DL. 2003. Phosphorus acquisition and use: citical adaptations by plants for securing a nonrenewable resource. New Phytologist 157:423-447.

Vitousek PM, Aber JD, Howarth RH, Likens GE, Matson PA, Schindler DW, Schlesinger WH and Tilman DG. 1997. Human alteration of the global nitrogen cycle: surce and consequences. Ecological Applications 7:737-750.

Waksman SA. 1936. Humus: origin, chemical composition, and importance in nature. The Williams \& Wilkins Company, Baltimore.

Wall DH and Moore JC. 1999. Interactions underground: sil biodiversity, mutualism, and ecosystem processes. Bioscience 49:109-117.

Wander MM and Traina SJ. 1996. Organic matter fractions from organically and conventionally managed soils: II. Characterization of composition. Soil Science Society of America Journal 60:1087-1094.

Wedin DA and Tilman D. 1990. Species effects on nitrogencycling a test with perennial grasses. Oecologia 84:433-441.

Welch LF, Mulvaney DL, Oldham MG, Boone LV and Pendleton JW. 1971. Corn yields with fall spring and sidedress nitrogen. Agronomy Journal 63:119-123.

Whitelaw MA, Harden TJ and Helyar KR. 1999. Phosphate solubilisation in solution culture by the soil fungus Penicillium radicum. Soil Biology and Biochemistry 31:655-665.

Whitman WB, Coleman DC and Wiebe WJ. 1998. Prokaryotes: the unseen majority. Proceedings of the National Academy of Sciences of the United States of America 95:6578-6583.

Wolt JD. 2004. A meta-evaluation of nitrapyrin agronomic and environmental effectiveness with emphasis on corn production in the Midwestern USA. Nutrient Cycling in Agroecosystems 69:23-41.

Zak DR, Tilman D, Parmenter RR, Rice CW, Fisher FM, Vose J, Milchunas D and Martin CW. 1994. Plant production and soil microorganisms in late-successional ecosystems: a continental-scale study. Ecology 75:2333-2347. 
Figure 1.

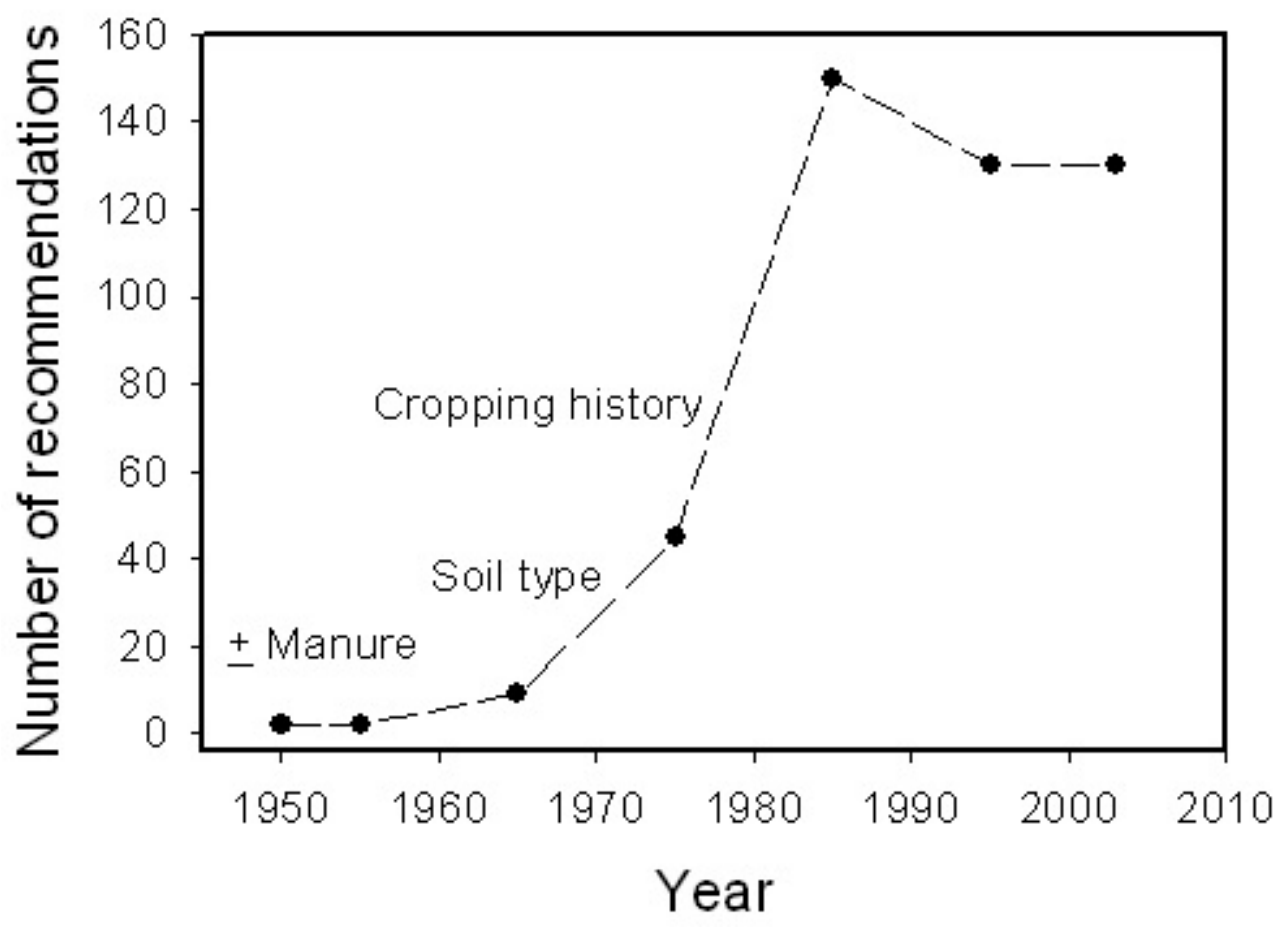


Figure 2a.

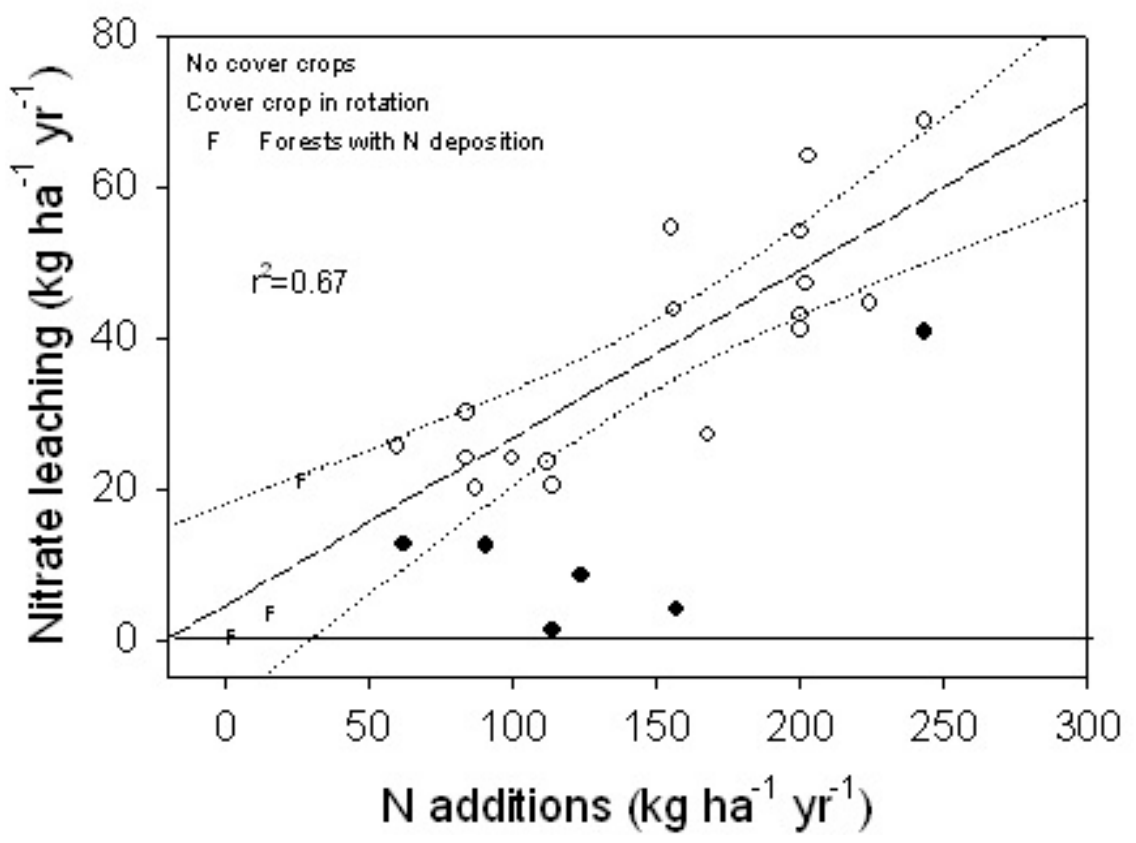

Figure 2b.

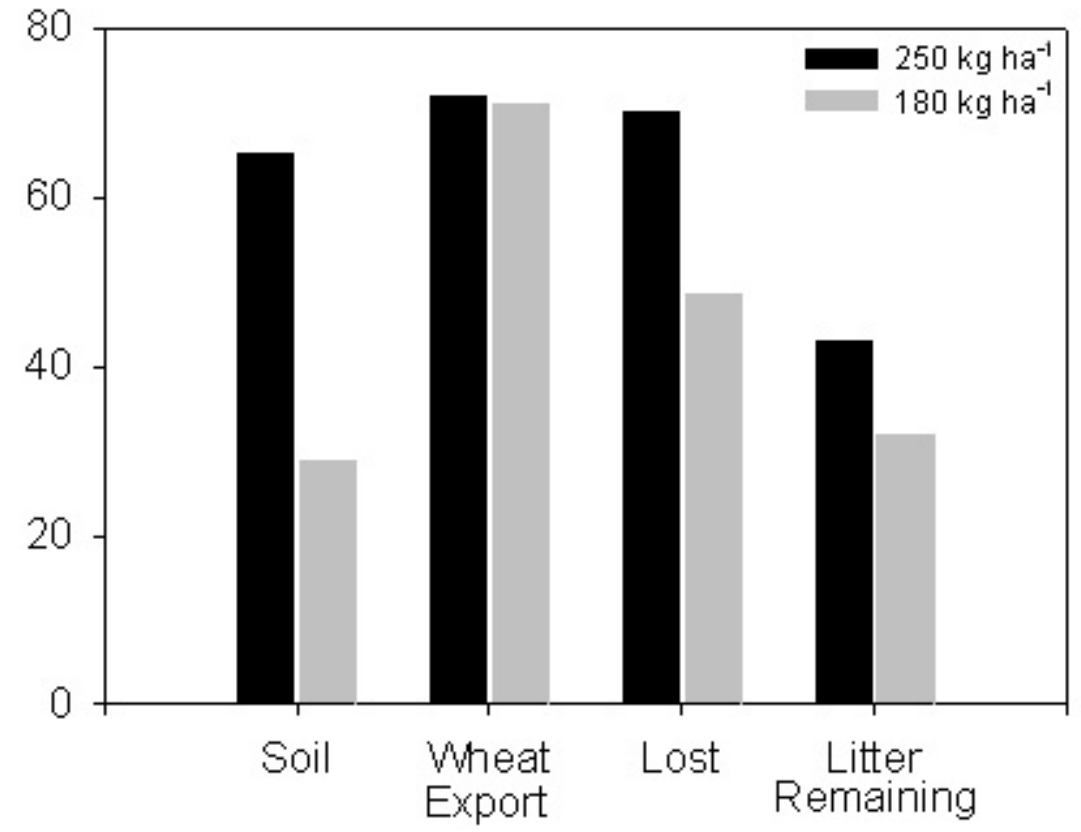


Figure 3.

\section{Conceptual framework for an ecological approach to nutrient management}

\section{Current model}

\section{Nutrient supply}

- Primarily soluble, inorganic fertilizers $\left(F_{i}\right)$

-Provide an optimum

delivery system for $F_{i}$

- Use soil tests to predict

plant available $P$ and net $N$

mineralization then match $\mathrm{F}_{\mathrm{i}}$

applications accordingly

\section{Soil pools actively managed}

- Inorganic N, extractable P

\section{Plant-mediated processes}

- Manage crop to create a

strong sink for $F_{i}$

- Remove all growth limiting

factors

\section{Ecosystem model}

- Strategic use of a variety of nutrient sources

- Maintain reservoirs with longer MRT's that can be accessed by plants and microbes

-Promote exchanges of $\mathrm{C}, \mathrm{N}$ and $P$ between primary producers and decomposers

- All $N$ and $P$ pools, organic and inorganic

- Maximize C-fixation, N \& $P$ assimilation in time and space through increased plant diversity

\section{Microbial and abiotic transformations}

- Chemical additives to inhibit nitrification and

denitrification

- Reduce surface area of

fertilizer patches

- Optimize pH to reduce P-

fixation
- Reduce the size of soluble inorganic nutrient pools

- Promote microbial uptake and humification

- Promote plant-mediated microbial transfomations that supply nutrients
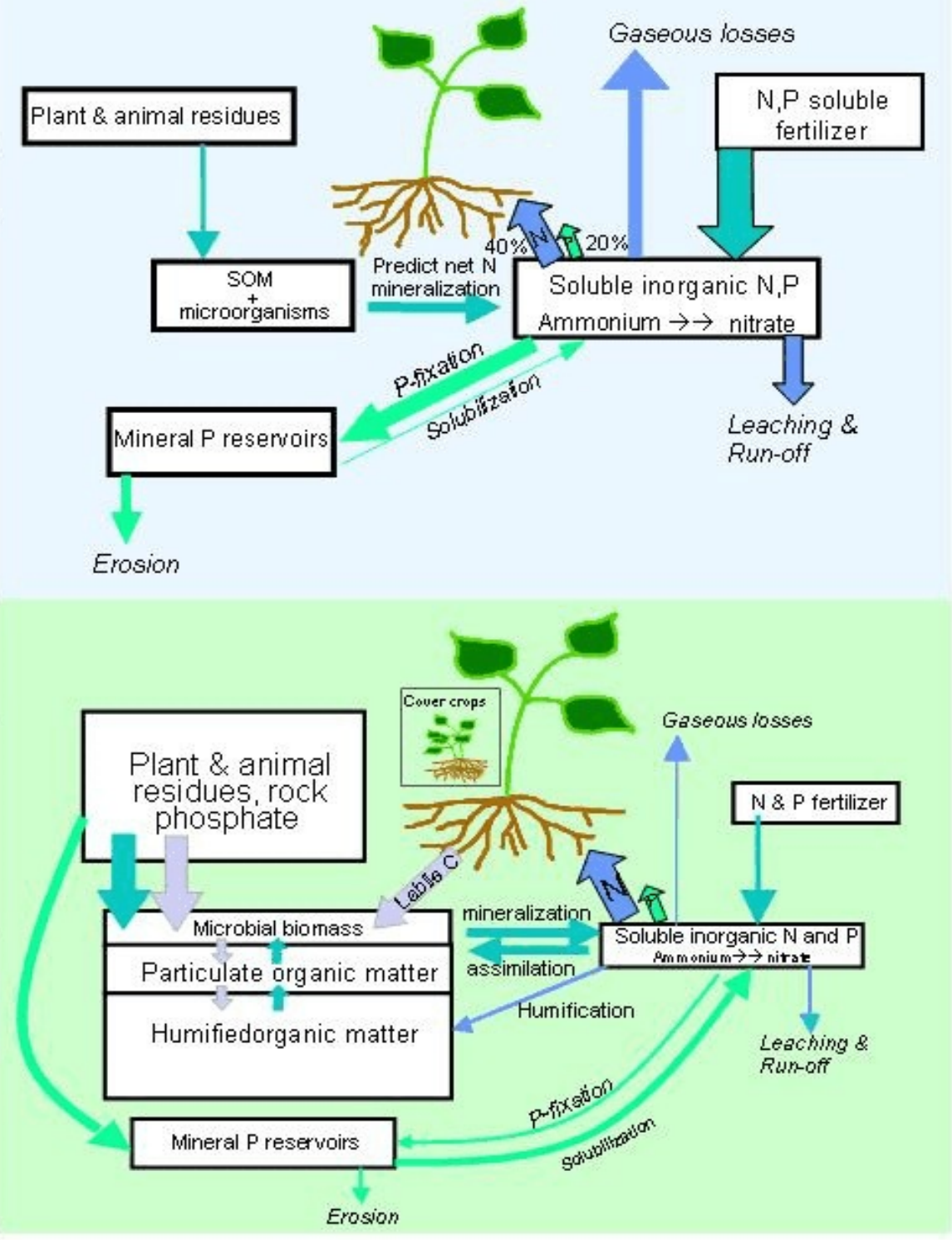